\title{
SEJARAH KEBANGKITAN MADRASAH SEBAGAI LEMBAGA PENDIDIKAN AGAMA ISLAM DALAM PANDANGAN GEORGE MAKDISI
}

\author{
Mufiqur Rahman \\ Institut Agama Islam Al-Khairat Pamekasan, Indonesia \\ E-mail: maufiqurrahmansurahman@gmail.com \\ Ummi Mahmudah \\ Institut Agama Islam Negeri Madura, Indonesia \\ Email: ummimahmudah.2018@gmail.com
}

\begin{abstract}
Abstrak: Tulisan ini akan fokus pada kebangkitan madrasah sebagai lembaga pendidikan Agama Islam dalam pandangan George Makdisi. George Makdisi sendiri merupakan salah satu sejarawan barat yang sangat konsen terhadap sejarah pendidikan Islam. Salah satu karyanya yang monumental adalah The Rise of Humanism in Clasisical Islam and the Christian West. Makdisi berpandangan bahwa Madrasah yang pertama kali muncul adalah madrasah Nidzomiyah. Dan yang menjadi platform dalam pembelajaran di Institusi formal ini adalah untuk mendidik para ahli hukum fiqih (lanyer) dan seni dalam literasi. Di mana outcome/alumnus adalah sebagai konsultan hukum (jurisconsult) dan juga sebagai literary arts of adab. Walaupun di balik Madrasah ada motivasi-motivasi yang menurut Makdisi sangat Politis. Makdisi memberikan pandangan bahwa Madrasa memiliki multi fungsi baik dalam navigasi politik, ekonomi dan sosial pada masa al-Mulk menjadi perdana menteri dan disebut sebagai tokoh yang melekat dengan nama besar Madrasa.

Kata kunci: kebangkitan, madrasah, lembaga pendidikan agama Islam, George Makdisi
\end{abstract}

\section{Pendahuluan}

Dari namanya George Makdisi, dapat kita lihat kata George adalah nama berkebangsaan Amerika dan Makdisi dari nama Arab. Dari dua kata tersebut sebenarnya dapat diketahui bahwa George Makdisi merupakan kelahiran Detroit, Michigan pada tahun 1920. Nama lengkapnya George Abraham Makdisi. Seorang Amerika dengan campuran Arab atau yang disebut dengan Arab American. Sejak tahun 1970 jumlah Arab Americans bertambah di Amerika, dampak arena perang ekonomi (wars and economic) di Negara Arab. Dan kemudian diestimasikan pata tahun 2000, ada kisaran 4.2 juta Arab Americans yang hidup di Amerika. Dia meninggal di Media, Pennsylvania pada 6 September 2002. Seorang Prefessor studi oriental, belajar di Amerika dan Lebanon dan lulus pada tahun 1964 di Perancis dari Universitas Paris Sorbone. ${ }^{1}$

Sebagai dosen di University of Michigan dan Harvard University, sebelum menjadi professor di University Pennsylvania tahun 1973 sebagai professor di bidang Arabic. Namun secara khusus Makdisi ahli di masalah isu pendidikan tinggi di dunia. Dia mempublikasikan karyanya The Fundamental of Principles of Jurisprudence yang terbit dalam tiga volume di German. ${ }^{2}$

Makdisi mempelajari dan menguasai sejarah perkembangan Islam dalam gerakan intelektual muslim secara mendalam. Ia menjelaskan tentang dua gerakan utama yang menjadi kajian utama

\footnotetext{
${ }^{1}$ George Makdisi, obituary cavanaghfuneralhome.com Retrived July 31, 2018 visit George Makdisi-Wikipedia dalam http://en.mwikipedia.org

2 Wikipedia, George Makdisi.
} 
dalam kajian sejarah perkembangan pendidikan Islam dalam dunia barat. ${ }^{3}$ Gerakan pertama adalah, Skolastik (scholasticism), ${ }^{4}$ adalah sekolah pada masa abad 9 sampai dengan 15 Masehi dengan pendekatan rasionalitas dan juga spritualitas yang juga pendekatan kemanusiaan (bumanism) masa periode kebangkitan bangsa Italia atau Italian renaissance. Mereka mendatangi Kristen Barat (Christian West) sekitar 1100 arus kitab Arab dari berbagai disiplin ilmu Islam yang diambil dari Spanyol dan Sisilia untuk dijadikan rujukan dan pemikiran sejarah yang berdasar pada sistem klasikal arab Islam dari abad ke 7 sampai 15, termasuk diantaranya Barat Latin dan Byzantium. Saat itu barat belum memiliki kemajuan dibidang pendidikan klasikal seperti di Arab, yang dalam peradaban Islam telah ada nama universitas atau disebut dengan Arabo Islamic. ${ }^{5}$

Institusi Islam pada waktu itu, dibedakan menjadi dua pertama adalah sekolah hukum (schools of law) dan perguruan tinggi hukum (colleges of law). Dengan terma yang berbeda yang disesuaikan dengan konstruksi disiplin keilmuan. Untuk school of law, Makdisi mendefinisikan bahwa hal tersebut adalah tempat dimana sebuah kelompok konsultan hukum yang berbagi pengalaman tentang hukum. Dan yang kedua disebut dengan geographical schools dimana perguruan tinggi hukum (colleges of law) dimaksudkan untuk sebagai tempat dan pengikut konsultan hukum, atau yang disebut dengan personal schools. School of law yang popular dan familiar dengan terma madzhab, dan colleges of law familiar dengan term madrasa. ${ }^{6}$

Karena sentralisasinya madrasa, maka institusi Islam dibagi menjadi dua: Pra Madrasah dan Pasca Madrasah. Karena Islam memisahkan diri dari Materi Islam atau kurikulum Islam dengan ilmu, hal ini sering disebut dengan foreign sciences atau ilmu asing (ilmu umum). Lembaga sebelum madrasah secara umum dibagi secara ekslusif dan inklusif ilmu pengetahuan. Masa sebelum madrasah bersifat tertutup yang diselenggarakan melalui metode halaqoh di Masjid. ${ }^{7}$ Periode Kuttab atau Maktab dan Masjid menurut banyak pakar adalah periode pra madrasah, disebut juga sebagai permulaan tumbuh dan lahirnya lembaga-lembaga pendidikan Islam. Yang berlangsung secara informal di rumah-rumah. Rumah al-Arqam Ibn Abi al-Arqam menjadi tempat belajar. Disebut juga tempat dakwah hingga abad ke 4 dan 5 lahirnya madrasah seperti munculnya

\footnotetext{
${ }^{3}$ George Makdisi, The Rise of Humanism in Classical Islam and The Christian West with Special Reference to Scholasticism (Edinburgh: Edinburgh University, 1990)

${ }_{4}$ Adalah nama sebuah periode pada abad pertengahan yang dimulai sejak abad ke-9 hingga abad ke-15 masa ini ditandai dengan munculnya banyak sekolah (dalam bahasa latin Schola) berbasis keagamaan dan banyak pengajar ulung menganalisis pemecahan masalah dogmatis secara rasional. Selain itu Skolastik juga merujuk pada metode keilmuan tertentu berbasis dogmatika rasional untuk memecahkan masalah keilmuan melalui spiritual barat. Baca Simon Petrus L Tjahjadi, Petualangan intelektual (Yogyakarta: Kanisius, 2004), 104-105.

${ }_{5}$ George Makdisi, The Rise of Humanism in Classical Islam and The Christian West with Special Reference to Scholasticism (inside cover) (Edinburgh: Edinburgh University Press. 1981), 1.

${ }^{6}$ Makdisi. The Rise of Colleges: 1.

${ }^{7}$ Makdisi. The Rise of Colleges: 1.
} 
Madrasah di Naisapur Iran (sekitar $400 \mathrm{H}$ ) dan Madrasah Nidzomiyah di Baghdad $(457 \mathrm{H}){ }^{8}$ Walaupun dalam konteks ini George Maksidi dan Ahmad Syalabi berpendapat madrasah pertama kali adalah madrasah Nidzomiyah di Baghdad yang didirikan oleh Wazir Nidhom al-Mulk tahun $457 \mathrm{H}$, namun penelitian lebih mutakhir menyebutkan bahwa Madrasah di Naisaphur justru muncul lebih awal. ${ }^{9}$

Namun karena madrasah dalam perspektif Maksidi adalah Madrasah Nidzomiyah yang memperesentasikan madrasah dan Naisaphur disebut Maksidi belum mempresentasikan madrasah secara umum dengan berbagai alasan akademik dan politis maka penulis dalam artikel ini akan mengikuti perspektif Maksidi dengan memposisikan Nidzomiyah sebagai awal munculnya madrasah dalam sejarah Islam yang datang dengan sistem modern sebagai lembaga pendidikan formal dengan tidak mengenyampingkan pendapat lain dan juga dalam rangka menghormati perjuangan al-Mulk dalam mempopulerkan madrasah hingga menjadi lembaga institusi Islam yang di kenal di dunia. ${ }^{10}$

\section{Madrasah dan Humanism}

Menurut Makdisi yang menjadi semangat awal dan persiapan awal (propaedentic) dalam pembelajaran madrasah adalah studi tentang adab humanisme (bumanistic studies of adab) dimana materi ini disampaikan sebagai sebagai persiapan menuju religious science. ${ }^{11}$ Kajian tentang humanism tidak pernah lepas dari kajian wawasan keagamaan. Sehingga yang ahli dalam bidang humanism ahli juga di bidang agama, dan juga ahli di bidang ilmu asing (umum), ${ }^{12}$ sehingga dalam konteks ini menurut penulis madrasah sejak awal berdirinya tidak ada dikotomi ilmu pengetahuan, tidak ada spesialiasi (takhsis) pengkhususan dalam belajar. Kajan humanism diajarkan dalam sebuah majlis, dalam sebuah kelompok kecil, dalam akademi, di rumah, di pusat belanja, dan juga di luar (out door). Namun yang paling urgen dalam tempat ini adalah dilaksanakan secara professional di madrasah, dimana madrasah memiliki koneksi dengan kekuasaan pemerintah dan secara formal tercatat dalam sebuah administrasi Negara. Inilah madrasah yang berperan sangat penting yang menjadi pusat pendidikan bagi anak sultan, anak dari perdana menteri, dan anak

\footnotetext{
${ }^{8}$ Mohammad Kosim, "Madrasah di Indonesia; Pertumbuhan dan perkembangan", Jurnal Tadris, Volume 2, Nomor 1, 2007, 43. .

${ }^{9}$ Kosim, Jurnal Tadris, 43. Baca juga Azyumardi Azra, Pendidikan Islam; Tradisi dan Modernisasi Menuju Millennium Baru (Jakarta: Logos, 1999), vii-viii.

10 Walaupun hasil penelitian mutakhir mengatakan ada madrasah sebelumnya di Iran namun al-Mulk berjasa mempopulerkannya bersamaan dengan reputasinya sebagai wazir. Siswanto mengatakan bahwa begitu dominannya peran Nizham al-Mulk terkadang mendorong kepada kesimpulan yang keliru dengan mengatakan bahwa Nizham alMulk adalah orang yang pertama yang membangun madrasah, sebagaimana yang dikemukakan Ahmad Amin dengan merujuk al-Dzahabi. Baca Siswanto, "Kebangkitan Madrasah Di Dunia Islam: Kajian Sosio-Historis tentang Madrasah Nizhamiyah", Tadris. Volume 3. Nomor 1, 2008, 75.

${ }^{11}$ Makdisi, The rise of Humanism in Classical Islam and the Christian West (Edinburgh : University Press, 1990), 60

12 Makdisi, The rise of Humanism, 60

144 | Tarbiyatuna: Jurnal Pendidikan Islam; Volume 13, Nomor 2, Agustus 2020, 142-150 p-ISSN: 2085-6539; e-ISSN: 2242-4579
} 
pejabat pemerintah lainnya didik disini. Yang akhirnya menjadi out come dari sebuah madrasah yang menguatkan kekuatan pemerintah. ${ }^{13}$ Walaupun ada juga yang menyebut madrasah sebagai institusi tradisional (traditional institution). Hal ini terjadi karena madrasah dianggap mengabaikan (ignored) ilmu sains modern dalam kurikulumnya. Yang dalam konteks ini disebutkan bahwa madrasah hanya untuk menghafal al-Quran. ${ }^{14}$ Tidak ada ukuran dan alasan untuk mengukur sebuah level atau jenjang dalam pembelajaran madrasah waktu itu. Dalam bentuk klasikal madrasah adalah institusi yang secara partikular par excellence, yang mengkhususkan pada tingkat awal dalam studi hukum dan Islamic sciences dan ilmu yang lain sebagai pendukung. ${ }^{15}$ Asumsi ini diperkuat oleh Makdisi, antara lain bahwa masjid khan yang menjadi cikal bakal madrasah dan fiqh merupakan bidang studi utamanya. ${ }^{16}$

Meski tujuan madrasah adalah mencetak dan mendidik para ahli hukum (fiqih) atau lanyer dan seni dalam literasi. Dimana outcome yang ingin dicapai oleh para alumnus adalah sebagai konsultan hukum (jurisconsult) dan juga sebagai literary arts of adab. Sehingga alumnus dari Nidzomiyah dapat disebut legal scholar atau man of letter, seperti yang sangat terkenal Imad ad-Din al-Katib al-Ishfahami (597-1201) sebagai kanselir atau senior dari Nur ad-Din Zangi (regnum ${ }^{17}$ 541-69/1146-74) dia juga sebagai sekretaris Saladin, dan sahabat, kolega dari al-Qodi’ al-Fadil alBaisani (596-1200) keduanya merupakan konselor dan founder dan juga epistolographer pada madrasa di Mu’izziya di Kairo dalam studi hukum. ${ }^{18}$

\section{Kurikulum Madrasah}

Kurikulum adalah bagian dari sistem pembelajaran, namun menurut Makdisi kurikulum dalam pengertian praktek pembelajaran dalam konteks madrasah adalah mengikuti gaya professor (style of the professor) dimana tidak lepas dari pengalamannya menjadi pelajar. ${ }^{19}$ Artinya sistem pembelajaran belum di-manage dengan baik. Beberapa materi ajar sebagai kurikulum muslim khusus untuk (bigher level of education) saat itu adalah Matematika (algebra, trigometri, dan geometri), Sains (ekonomi, fisika dan astronomi), obat Medicine (anatomi, surgery, parmasi, dan specialist medical), Filsafat (logic, ethics, dan metaphysics), Literatur (filologi, grammar, sajak, dan prosa), ilmu sosial (sejarah, geografi, disiplin politik, hukum, sosiologi, psikologi, dan yurisprodensi) Teologi (perbandingan agama, sejarah agama, studi al-quran, hadis dan topik keagamaan), bahkan

\footnotetext{
${ }^{13}$ Makdisi, The rise of Humanism, 60

${ }^{14}$ Halimatussa'diya, the Thought of George Makdisi on Classical Islamic Colleges (madrasa) dalam (Tesis UINSU, Sumatera Utara, 2013, 35. Lihat juga Cyril Glasse, Ensiklopedi Islam, Translated by Ghufron A. Mas'adi, ed 1, cet. 3, (Jakarta: RajaGrafindo Persada, 2002).

${ }^{15}$ Makdisi, The Rise of Humanism, 9.

16 Siswanto, Kebangkitan Madrasab 73.

${ }^{17}$ Bahasa latin artinya tingkatan paling atas dari tingkatan klasifikasi dalam sebuah kerajaan

${ }^{18}$ Makdisi, The Rise of Humanism, 9.

${ }^{19}$ Halimatussa'diya, the Thought of George Makdisi 37.
} 
madrasah menawarkan program lanjutan (advanced studies) sebagai program profesi sebagai praktisi hukum dan kedokteran. ${ }^{20}$

Kemudian adanya indikasi kurikulum muslim termanifestasi dalam kamus Arab (Arabic dictionary) yang terdiri dari 60 volume yang mengilustrasikan sebuah pembelajaran tentang ilmu mengukur bentuk bumi, menghitung proses pergantian bulan (ilmu falaq), penemuan jam, grativitas, menggunakan alat (globe) dalam pembelajaran geografi bumi, melakukan observasi secara emperis tentang tubuh. Kemudian mengembangkan penggunaan obat-obatan terlarang (drugs), herbal, dan makanan untuk sistem perobatan. Kemudian menjadikan sistem rumah sakit dalam bentuk internal dan eksternal. Kemudian meningkatkan ilmu navigasi, dan menampilkan serta memperkenalkan konsep irigasi, fertilasi, dan cara menyuburkan tanah saat bercocok tanam, menemukan konsep higienis dalam lingkungan, dan membuat anastesi dalam melakukan praktik operasi (surgery) dengan alat surgery yang terbaru. Kemudian memperkenalkan ilmu pembedahan dalam anatomi. Meningkatkan ilmu pembiakan hewan peliharaan, dan menemukan cara baru dalam okulasi untuk memproduksi jenis bunga dan buah. Pada Area atau wilayah kimia, kurikulum diarahkan kepada penemuan baru dalam kalium karbonat, alkohol, garam asam sendawa dalam perak, asam sendawa, asam belerang, dan sublimasi korosif yang kemudian dipakai salah satu bahan tekstil, karamik, dan pengerjaan logam. ${ }^{21}$

Kemudian yang menjadi konsentrasi juga dalam kurikulum muslim pada pertengahan periode Abbasiyah adalah penyajian oleh Abu Yahya Zakariya tentang legal subject (syariah) dan literary studies (adabiyat) dan matematik (riyadiyat), dan rasio (aqliyat). Bencana besar kemudian datang kepada pelajar muslim yaitu bencana invasi pasukan Mongol pada abad ke 13. Mongol menghancurkan institusi besar di Khurasan dan Banghdad, mereka menghancurkan Masjid, universitas, dan perpustakaan muslim. Setelah bencana tersebut, muslim tidak mendapatkan kembali semangat mereka dalam keilmuan yang gemilang. ${ }^{22}$ Walaupun demikian Muslim masih mendapatkan informasi dari beberapa skop Islam pada abad ke 10 yaitu dari tiga sumber otentik yaitu pertama, Al-Fibrist al-Ulum (index of the sciences) karya Ibn al-Nadhim (988). Kedua, The Works of the Society of Encyclopedias yang dikenal dengan Ikhwan al-Safa (Brethren of purity) dan ketiga, adalah Mafatih al-Ulum (Keys of science) karya Yusuf of Khawarizm (976). ${ }^{23}$

\footnotetext{
${ }^{20}$ Sedangkan kurikulum vocational sangat beragam dan diimplentasikan dalam studi umum (general studies) beberapa materi vocational secara umum dapat didapatkan melalui Encyclopedia of the Ikhwan al-Safa yang sangat terknal dan sangat dihormati oleh sekolah di Eropa. Baca Makdisi, The Rise of Humanism in Classical Islam and The Christian West, 52.

${ }^{21}$ Makdisi, The Rise of Humanism in Classical Islam, 53.

22 Makdisi, The Rise of Humanism in Classical Islam, 53.

${ }^{23}$ Makdisi, The Rise of Humanism in Classical Islam, 53.

146 | Tarbiyatuna: Jurnal Pendidikan Islam; Volume 13, Nomor 2, Agustus 2020, 142-150 p-ISSN: 2085-6539; e-ISSN: 2242-4579
} 


\section{Sumberdaya Manusia Madrasah Nidzomiyah}

Ada banyak ilmuan yang lahir sebab itu, antara lain Shafíi (204/820) seorang yang ahli di bidang hadis dan menggunakan metode mudhakara, diskusi, dan nazar. Ada juga Abu'l-Hasan an Nahwi (320/932) ahli di bidang gramatika menurut Abu Haiyan at-Tauhidi (414/1023) ia memulai pembelajaran dengan pembacaan quran dengan bacaan yang berbeda. Kemudian menjelaskan tentang hadis. Dia berceramah dan melakukan elaborasi, dan bertanya. Dia juga melakukan metode sorogan pada malam hari. Kemudian Ibn Abi Muslim al-Farabi (406-1016). Konsultan hukum dan ahli dalam baca Quran. Ibn Abi Muslim al-Faradi, memulai kelas dengan membaca Quran. Muridnya datang dari banyak kalangan (semua jenjang) dia juga mengajarkan hadis dengan cara imla'. Kemudian berikut ini adalah beberapa tokoh pembelajar Nidzomiyah: Abu'l-Qasim alQushairi (465-1073). Ia adalah pengarang Risala on Sufism, dia mendapat gelar ('allama_sangat alim) dalam ilmu fiqh, hadith, usul, adab-literature, sajak, seni menulis (kitabab) dan dunia sufi. Kemudian Abu 'Ali al-Fariqi (528/1134). Seorang Residen dari Maiya fariqin, Abu 'Ali al-Fariqi, lair pada tahun 433/1042, ia belajar fiqih kepada Abu 'Abd Allah Muhammad al-Kazaruni (455/1063). Setelah Kazaruni meninggal pada 455 H., Fariqi belajar kepada Abu Ishaq ash-Shirazi in Baghdad, 456 H. Waktu itu ia berumur 23 tahun. Ia belajar pada Shirazi's law course selama 4 tahun, dan belajar fiqih pada Ibn as-Sabbagh, dan akhirnya dia menjadi professor di bidang hukum. Kemudian Ibn al-Waqshi of Toledo (489-1096). Ahli di bidang sajak, retorika dan menulis sastra, dia juga seorang orator, pakar hadith, fiqih, ahli dalam administrasi hukum, dan kalam, logika, geometri, genealogi, dan menarasikan tentang riwayat kematian Nabi, dan juga ahli di bidang hukum internasional. Kemudian 'Abd al-Ghafr al-Farisi (529-1134). Sebagai cucu dari Abu al-Qasim al-Qushairi dan Abu 'Ali ad-Daqqaq (405/1015). Ia lahir 451/1059. Dia alumni maktab dimana ia belajar baca Quran dan belajar hadith pada tahun 457. Kemudian Abu Bakr b. 'Abd al-Baqi (535/1141). Lahir 442/1050, Abu Bakr b. Abd al-Baqi belajar Quran sejak umur 7 tahun, dan mulai belajar hadith pada $445 \mathrm{H}$. Ia pakar bahasa Yunani dan pakar dalam matematika. Dia banyak menterjemahkan buku Yunani ke dalam bahasa Latin. Kemudian Al-Luraqi of Andalusia (fl. 618/1221). Seorang muslim berkebangsaan Spanyol, al-Luraqi belajar quran di Murcia dan Valencia. Dia berangkat ke Mesir 601/1204 Mendalami ilmu quran, dan di Damaskus 603/1026 belajar quran dan Literatur. Dia belajar Gramatika Sibawaih, al-Kitab; dari Damaskus, kemudian dia berngkat ke Baghdad dan belajar al-Khatib al-Baghdadi's biographical work, Tarikh Baghdad. Yang terakhir adalah Al-Qifti (646-1248). Ahli Gramatika fiqh, hadis, ilmu quran, usul, logika, matematika, astronomi, geometri, sejarah, dan kritik hadits ('ilm al-jarh wa 't-ta'di). ${ }^{24}$

\footnotetext{
${ }^{24}$ Halimatussa'diya, the Thought of George Makdisi, 36-39. Baca juga George Makdisi, The Rise of Colleges, Edinburgh: Edinburgh University, 1981.
} 
Dalam pengamatan penulis hampir semua guru besar madrasah Nidzomiyah menjadikan alquran sebagai awal dalam pembelajaran, karena sebenarnya alquran sebagai sumber dan dasar dalam kerangka epistemologi dalam Islam. Alquran tidak hanya menjadi sumber keimanan namun juga menjadi dasar dalam mencapai wawasan keilmuan. Menurut Zainuddin Syarif, di dalam alquran terdapat kerangka teoritik jika kita mampu menyingkapnya baik tersurat maupun tersirat. Perlu penelitian yang mendalam dan berkesinambungan, sebagaimana Syarif berpendapat bahwa untuk keperluan mengungkap sebuah konsep keilmuan dalam alquran perlu adanya integrasi dan interkoneksi keilmuan seperti yang dilakukan madrasah yang telah membuka beragam disiplin keilmuan. ${ }^{25}$

\section{Madrasah dan Politik}

Makdisi, sejarawan yang menyatakan bahwa Nidham al-Mulk sebagai seorang individu yang membangun membangun madrasah untuk kepentingan pribadi. Tidak dapat dinafikan dalam fakta sejarah melihat al-Mulk sebagai perdana menteri yang memiliki motivasi di balik madrasah. Makdisi menyatakan ada alasan dan peran politik di dalamnya (political reason). Tentunya sebagai perdana menteri, al-Mulk menginginkan sebuah stabilitas pemerintahan, maka ia merasa perlu untuk membangun sebuah ikatan hubungan Ulama Islam (Islamic scholars). Madrasah Nidhamiyah berfungsi sebagai alat (tool). Menjadikan madrasah sebagai alat untuk mendapatkan dukungan golongan/kelompok Syafi'iyah dan Asy'ariyah. Mereka yang belajar dan mengajar di madrasah berada di bawah kontrol al-Mulk dan melalui otoritasnya, al-Mulk memberikan kebijakan untuk memberikan waqf donation untuk kesejahteraan madrasah yang ada di kota-kota yang dianggap penting. Secara politik menurut Makdisi, madrasah memberikan navigasi politik yang sangat signifikan untuknya. Melalui madrasah, ia sukses mendapatkan dukungan (endorsement) dari Ulama besar dan terkenal (well-known Islamic scholars). Dan membangun kekuatan politik al-Mulk dalam dinasti Abbasiyah. ${ }^{26}$

Dalam sebuah artikelnya, Makdisi menyampaikan sebuah alasan kenapa Nidham al-Mulk memilih untuk mendirikan madrasah dalam titik yang luas dan dengan dana yang tidak sedikit. Yaitu untuk menguasai para pembelajaran di masjid (scholars in mosque) dan karena hanya madrasah yang memberikan dukungan besar kepada. Nidham al Mulk. Madrasah disebut Makdisi sebagai (the best institution) untuk setelahnya mendapatkan dukungan masjid-Jami', dan juga non-Jami, dimana Imam (religious leader) bertanggung jawab untuk menjadi perekat, dan bahkan madrasah menjadi panitia administrasi terhadap adanya madzhab. Jadi untuk memanipulasi Masjid sangat

\footnotetext{
25 Zainuddin Syarif, "Pengembangan Pendidikan dalam Perspektif Epistemologi Islam", Tadris, volume 2, nomor 2, 2007, 200

26 Syarif, Pengembangan Pendidikan, 56.

148 | Tarbiyatuna: Jurnal Pendidikan Islam; Volume 13, Nomor 2, Agustus 2020, 142-150 p-ISSN: 2085-6539; e-ISSN: 2242-4579
} 
tidak mungkin dilakkan oleh al-Mulk, jalan yang terbaik adalah memegang otoritas masjid dengan madrasah sebagai lembaga yang memberikan catatan administrasi terhadap sebuah madzhab. ${ }^{27}$

\section{Kesimpulan}

Makdisi memberikan pandangan bahwa madrasah memiliki multi fungsi baik dalam navigasi politik, ekonomi dan sosial pada masa al-Mulk menjadi perdana menteri dan disebut sebagai tokoh yang melekat dengan nama besar madrasah. Disebut berperan dan berfungsi politis, karena dengan eksistensi madrasah, al-Mulk mendapatkan dukungan dan endorsement dari kalangan ulama besar dari kalangan Syafii'yyah dan Asy'ariyyah di masjid-masjid di daerah-daerah yang dianggap krusial dalam kekuasaan politik. Dalam konteks madrasah dan politik ini juga memberikan angin segar kepada kesejahteraan madrasah melalui kebijakan politik al-Mulk dalam memberikan donasi wakaf untuk madrasah. Di sinilah Makdisi menyebutkan bahwa al-Mulk berjasa dalam mempopulerkan madrasah dalam skala yang besar dan dengan dana yang tidak sedikit.

Kedua, disebut madrasah sebagai fungsi dalam ekonomi, karena kenyataannya keberadaan madrasah tidak lepas dari perhatian al-Mulk dan menjamin kehidupan madrasah sebagai lembaga formal yang memiliki hubungan dengan kekuasaan pemerintah. Ketiga, disebut juga sebagai fungsi sosial karena madrasah mengajarkan nilai-nilai kemanusian (bumanisme) atau disebut dengan adab atau akhlak. Sebagian besat outcome yang dihasilkan oleh Nidzomiyah adalah para ahli di bidang sains dan kajian tentang bumanism tidak pernah lepas dari kajian wawasan keagamaan. Sehingga yang ahli dalam bidang humanism ahli juga di bidang agama, dan juga ahli di bidang ilmu asing (umum), sehingga dalam konteks ini menurut penulis, madrasah sejak awal berdirinya tidak ada dikotomi ilmu pengetahuan.

\section{Referensi}

Azra, Azyumardi. 1999. Pendidikan Islam; Tradisi dan Modernisasi Menuju Millennium Baru, Jakarta: Logos.

Cyril Glasse. 2002. Ensiklopedi Islam, Translated by Ghufron A. Mas'adi, ed 1, cet. 3, Jakarta: RajaGrafindo Persada.

Halimatussa'diya, The Thought of George Makdisi on Classical Islamic Colleges (madrasa) (Thesis: Sumatera Utara: UINSU, 2013)

Kosim, Mohammad, "Madrasah di Indonesia; Pertumbuhan dan Perkembangan" dalam Jurnal Tadris, Volume 2, Nomor 1, 2007.

Makdisi, George, "Muslim Institutions of Learning in Eleventh-Century Baghdad,". In Bulletin of the School of Oriental and African Studies, vol. XXIV (1961)

27 George Makdisi, “ Muslim Institutions of learning in Eleventh-Century Baghdad,". In Bulletin of the School of Oriental and African Studies, vol. XXIV (1961), 51-52. Diambil dari hasil penelitian Halimatussa'diya, the Thought of George Makdisi on Classical Islamic Colleges, 56. 
1981. The Rise of Colleges, Edinburgh: Edinburgh University.

1990. The Rise of Humanism in Classical Islam and The Christian West with Special

Reference to Scholasticism, Edinburgh: Edinburgh University.

1990. The rise of Humanism in Classical Islam and the Christian West (Edinburgh: University Press.

The Rise of Humanism in Classical Islam and The Christian West with Special Reference to Scholasticism (inside cover).

Obituary cavanaghfuneralhome.com retrived July 31, 2018 visit Gerge MakdisiWikipedia dalam http://en.mwikipedia.org

Siswanto. 2008. Kebangkitan Madrasah di Dunia Islam: Kajian Sosio-Historis tentang Madrasah Nizhomiyah, Tadris, Volume 3. Nomor 1.

Syarif, Zainuddin, "Pengembangan Pendidikan dalam Perspektif Epistemologi Islam", Tadris, volume 2, nomor 2, 2007.

Tjahjadi, Simon Petrus L, 2004. Petualangan Intelektual, Yogyakarta: Kanisius. 